\title{
Between Bridges and Walls
}

\section{Attempts at Implementation of the Maritime \\ Mail Service Between Portugal and Brazil During the First Half of Eighteenth Century}

\section{Entre pontes e muros}

Tentativas de implantação do correio marítimo

entre Portugal e o Brasil na primeira metade do século XVIII

\author{
Romulo Valle SALVINO \\ Departamento de História \\ Universidade de Brasília \\ Campus Darcy Ribeiro, ICC-Norte, Bloco A, Subsolo (ASS679-690) \\ Brasília, DF, 70.910-900, Brasil \\ romulovs@uol.com.br
}

\begin{abstract}
During the first half of eighteenth century, there were several attempts to establish a logistical structure for a regular transport of correspondence, outside of the fleet regime, between Portugal and its American colonies. Based on some documents of the Portuguese Ultramarine Council, this article analyses some of these projects. One of the most important attempts must be attributed to Francisco Peres de Sousa, an assistant of the mail service for the state of Brazil, who had been a former music teacher and was a whale fishing contractor on the Brazilian coast. In general, and despite the vehement defense of important people like Alexandre de Gusmão, such projects could not be accomplished, finding a vigorous opposition of the businessmen gathered around the Brotherhood of Holy Spirit. In this article it
\end{abstract}

Received: 13 July 2017 | Reviewed by the author: 8 Oct. 2017 | Accepted 31 Oct. 2017 http://dx.doi.org/10.1590/0104-87752018000100002

Varia Historia, Belo Horizonte, vol. 34, n. 64, p. 15-49, jan/abr 2018 
is argued that the failure of these projects, a result of a dispute between different groups of businessmen from Lisbon, was also a consequence of divergent views on the geopolitical and geoeconomic articulations on the ultramarine monarchy. This failure could also be considered as a consequence of different ways of understanding the relationship between time and distance at that time. The study of these obscure episodes allows us to approach not only a neglected aspect of the history of written communication systems, this technology of distance control, but also to grasp the operation of the modern "paper empires" from a new perspective.

KEYWORDS written communication, maritime mail service, transatlantic correspondence

Resumo Na primeira metade do século XVIII, surgiram tentativas de se criar uma estrutura logística para o transporte regular de correspondências, fora do regime das frotas, entre Portugal e suas conquistas americanas. Com base em alguns documentos do Conselho Ultramarino Português, este artigo analisa algumas delas, dentre as quais avulta a de Francisco Peres de Sousa, assistente do correio-mor para o estado do Brasil, ex-professor de música e futuro contratador da pesca de baleias na costa brasileira. Tais projetos, alvos de forte oposição dos homens de negócio da Confraria do Espírito Santo, acabaram por não se concretizar, apesar da defesa veemente de figuras como Alexandre de Gusmão. Neste artigo, argumenta-se que esse malogro, resultado de disputas entre diferentes grupos de homens de negócio de Lisboa, foi consequência também de distintas visões sobre a articulação geopolítica e geoeconômica da monarquia ultramarina e de diferentes formas de compreender a relação entre o tempo e a distância. O estudo desses episódios obscuros permite aproximar-se não só de um aspecto negligenciado da história dos sistemas de comunicação escrita, essa tecnologia de domínio da distância, mas de lançar um novo olhar sobre o funcionamento dos "impérios de papel” modernos.

Palavras chave comunicação escrita, correios marítimos, correspondência transatlântica 


\section{THE EMERGENCE OF MODERN POSTAL SYSTEMS AND THE PORTUGUESE MAIL SERVICE CASE}

I begin this article by stating a truism. Until a relatively recent past at the turn of nineteenth to twentieth century, when the telephone, the radio and the wireless telegraph emerged - the only available technology for long distance communication was the writing. Spatial and geographical separation was a inescapable matter, to which the letters could, if not give a complete solution, offer a palliative at least: "Since the distance between places has set us apart, I will frequently speak with you through letters". 'Subjected to long journeys by land and to the uncertainties of sea, the correspondences emerged as an important means of communication in a continuous enlarging world. They gathered together people who were kept apart due to their personal trajectories, connected the different domains which were important for the operation of monarchies, and put in contact tradesmen who were kept apart by long days and months of journey. Thus, it is not by chance that great empires and commercial corporations had been concerned about the establishment of logistical systems and regulatory marks to organize mail exchanges in regions of their interest. It is not by chance that the organization of mail services potentially accessible to everyone, through a system of rates previously determined, has mainly occurred from the nineteenth century, by adopting the great commercial and migratory routes which crossed Europe.

In spite of being evident, the identification of the importance of written communication in modern age is not always explored by Portuguese-language historians in many of its possible fronts and consequences. Normally, the studies, with few exceptions, aimed at the content of the messages, which were used until then as historical sources with different purposes rather than as significant elements of material and institutional aspects of written communication, and which were

1 BLUTEAU, Raphael. Vocabulario portuguez \& latino... Coimbra: Real Collegio das Artes da Companhia de Jesus; Lisboa: Officina de Pascoal da Sylva, 1713, v. 3, p.254. 
understood themselves as possible objects of research. In German, English, French, and Spanish historiography, in addition to works concerned mainly about cultural, social, and political interfaces of written communication - one can remember, for instance, Fernando Bouza's (2001), Antonio Castillo Gómez's (2006), Filippo de Vivo's (2007; 2012) and Arndt Brendecke's (2012) - other works have swelled, which are aimed at the history of mail services with more emphasis, even if they are official or not, and they are also aimed at governor's, tradesmen's and common people's strategies to spread their mails. That is the case of Ian K. Steele's (1986), Francisco Garay Unibaso's (1987), Wolfgang Behringer's (2006), Didier Gazagnadou’s (2013), Sylvia Sellers-García’s (2014) and Jay Caplan's (2016) works, among others. There is even a work on Hispanic American mail services by a Brazilian historian named Manoel Lelo Belotto (1971), which has become a reference. In Portugal and Brazil, some compilations have appeared over recent decades focusing on the use of letters, either in a broader scope of written culture (Algranti; Megiani, 2009), or in a more specific way, by concerning about the epistolary universe (Anastácio, 2004). There are even studies which approach missives as elements of political communication, which can be found in a recent book organized by João Fragoso and Nuno Gonçalo Monteiro (2017). The researches, however, with few exceptions, many of them cited in this paper, tend to be concerned neither about the shipping and delivery system of correspondences, nor about the services created over the time in order to manage the logistics required to move these correspondences, nor about the power games related to administrative and operational systems built to keep the circuit of written communication.

This article focuses on the disputes regarding the possibility of creating a service of packet boats between Lisbon and the main harbors in Portuguese America, from 1710 to 1745. The two main documents investigated are a Consultation of Ultramarine Council, dated February 1710, regarding a request made by a certain Manuel Álvares Nogueira to exploit mail ships between Lisbon and Brazil, and a request processed by the same department, in which the possibility of conceding the same 
privilege to the assistant of the postal service named Francisco Peres de Sousa is analyzed, dated September $1745 .^{2}$

Packet boats - also called, on consulted documents, in Portuguese spelling paquetes, paquebotes or pacabotes - were boats which should travel in predetermined routes and terms, with the sole or main purpose of carrying mails. They were equivalent, at sea, to the routes of regular or ordinary mail in land. The origin of this name is related to the ships which carried letters between Calais, in France, and Dover, in England (Cabanillas, 2014, p. 77). Father Vieira used one of those boats in his journey, because he considered them protected from corsairs, according to his letter dated $1647 .{ }^{3}$ Packet boats like these were launched between England and its American colonies, from 1702 and 1715, due to the War of the Spanish Succession (Steele, 1986, p. 168-188). They also traveled between Lisbon and the English habor in Falmouth, due to an agreement which was signed by the postal administrators of both countries, from 1705. In that case, the ships were paid by the English Crown, and the Portuguese mail service, on its part, made a commitment to pay six hundred réis for each ounce of letters which were received. ${ }^{4}$

However, before dealing with the packet boats, by the absence of works on the materiality and institucionality of written communication during Portuguese Old Regime, it is important to summarize the history

2 These two documents (both without numbered sheets) are respectively: LIVRO de registo de consultas mistas do Conselho Ultramarino, v.8. AHU_ACL_CU_005, Consultas mistas, Cod. 20; REQUERIMENTO do enfermeiro-mor e tesoureiro do hospital real ao rei [D. João V] solicitando conceder ao assistente do correio no Estado do Brasil Francisco Peres de Sousa o privilégio de ter prontos alguns paquebotes para irem a cada dois meses aos portos da Bahia, Pernambuco e Rio de Janeiro ... AHU-Bahia, cx. 108, doc. 42. AHU_ACL_CU_005, cx. 83. D. 6832. The last of those sources includes seven attachments. They will be cited in this article as "Consultation, 1710" and "Requerement, 1745".

3 VIEIRA, Antonio. Cartas do Padre Antonio Vieira. Lisboa: J.M.C. Seabra \& T.Q. Antunes, 1854, t.1, p.5.

4 TRATADO entre Portugal e Inglaterra para o estabelecimento de uma correspondência regular entre os dois países: apud CASTRO, José Ferreira Borges de; BIKER, Júlio Firmino Júdice (compil). Supplemento á collecção dos tratados, convenções, contratos e actos publicos celebrados entre a Corôa de Portugal e as mais potencias desde 1640. Lisboa: Imprensa Nacional, 1873-1879. t. 10, p. 173-181. 
of postal systems in that period. The organization of those services was related to certain people's concrete needs - both individual and collective -, who stood in different ways on proposed solutions at each time, according to their own interests, leading to conflicts which took different shapes over the time in different regions. There was no doubt that written communication contributed to common good, however, there were a lot of divergences regarding which systems and resources should be used to make it viable and effective. That happened because it was necessary to ensure not only the transit of letters, but also economical solutions related to desired deadlines and period of delivery.

The motif of exchanging mails as something able to gather together people who were kept apart, or as a way of talking to absent ones, was relatively common in texts of modern age, when there was a great population displacement. The book Vocabulario portuguez \& latino, for instance, defines the letter in a succinct and almost poetical way: "paper written by an absent one.". The theme of absence raises the matter of the loss and the affections caused by it: "the absence is felt due to an affection for things that are lost, because we don't know how much what we have is worth, and we feel the effects of love in privation rather than in achievement." ${ }^{\prime}$ However, if this affection was clearly stated in declared private communication, which can be seen by the quotation of literary passages, administrative or commercial messages needed to be mainly effective, that is, they needed to offer a way to overcome the distance, with the best cost-benefit relationship. And it is in this prosaic field where the main points touched by this research are placed. In this field,

5 BLUTEAU, Raphael. Vocabulario portuguez \& latino... Coimbra: Real Collegio das Artes da Companhia de Jesus; Lisboa: Officina de Pascoal da Sylva, 1712, v. 2, p.166. This definition may be a reverberation of Tesoro de la lengua castellana o española (1611) by Sebastián de Covarrubias, which is more than once quoted by Bluetau in other entries: "message which is sent to an absent by writing on any kind of material". COBARRUBIAS OROZCO, Don Sebastian de. Tesoro de la lengua castellana, o española. Madrid: Luis Sanchez, 1611. This is the original quotation: "mensagería que se embía al ausente por escrito en qualquer materia que sea". Translated by the author of this paper.

6 BLUTEAU, Raphael. Vocabulario portuguez \& latino... Coimbra: Real Collegio das Artes da Companhia de Jesus; Lisboa: Officina de Pascoal da Sylva, 1713, v. 1, p.681. 
some factors take shape, all of them maximized by distance, as the cost, the possibility of losses and gains by agents involved, the speed and regularity, as well as the safety (or the secret) of the communication and the advantages and risks of being controlled.

The awareness of distance in modern age, however, was not perceived as it is nowadays. The first reason lies on the relationship between space and time. Braudel pointed out that the Mediterranean region could be crossed, during Ancient Rome, at intervals which ranged from forty to seventy days, the same time spent to cross all the area that he named "space of world economy" by the time he wrote, in 1939 (Braudel, 1976, t. 1, p. 491-492). There was no substantial change between possible travel speed in Caesar's time and possible travel speed in sixteenth century, and nobody expected it to be different. Furthermore, the variation in journey length on the same route was accepted more naturally than it is today. That was the result of a reality in which road accidents were always expected.

Another difference between the understanding of distance in our age and the one in sixteenth and eighteenth centuries is related to distinct views on the binomial continuous/discontinuous. From a geographical point of view, the world and the monarchy were not perceived as great contiguous spaces, but they were perceived as insular groups which could be eventually connected by some aspects and for some purposes. The discontinuity was a rule of systemic functioning, not only from geographical point of view but also institutional. As Miguel Jasmins Rodrigues says:

The discontinuity is, thus, one of the structuring elements in the society of "Old Regime", to the same extent that it is this discontinuity, present and felt in the most different levels, which enables the coexistence and functional articulation of various structures of power/domination. Those structures are not integrated into pyramids according to our own model, on the contrary, they intersect and overlap in conjugate autonomies, even when they do not exclude the existence of a center. (Rodrigues, 2006, p. 13) 
According to this logic, communication would emerge as a possible "cohesion model" (Rodrigues, 2006, p. 17). Roads, maritime routes, merchant supply lines and mail routes emerged as structuring elements of monarchic body, more or less perennial. In the specific case of Portuguese transcontinental monarchy, one should remember the importance of letters in a space defined by distances which few centuries before would be unthinkable, and in which trips could last several months. Antônio Manuel Hespanha refers to a "paper empire", because it was the "complete implementation of written form that enabled the maintenance of public spaces spatially dispersed, such as those owned by Portuguese crown (Hespanha, 1994, p. 291). Besides being "governing instruments", the correspondences constituted the strands of relationship networks - or simply "networks", to remember a term used by Fragoso e Gouvêa (2010, p. 23). In such networks, people were placed in distinct social and geographical positions, with access to several resources and information, in a scenario where heterotopia lead to a dynamic of exchanges, where the existence of differences provided a possibility of getting new knowledge and earnings. A world where, to remember Braudel, news could be worth more than their weight in gold (Braudel, 1976, t. 1, p. 486). Letters assume, thus, an important function in the world of commerce, whose operations merged, many times, with the functioning of client networks itself. Possibilities of business were drawn on many different papers. That was true both in more distant times and in eighteenth century, both in Europe and in places farther from transcontinental monarchies. Referring to the specific case of Minas Gerais in the first decades of eighteenth century, Júnia Furtado says that, besides being "fundamental to reproduce social and political ties in an informal way", the correspondences "exchanged through merchant's networks at that time were essential to the good performance of economic operation" (Furtado, 2006, p. 59). Different kinds of news circulated through those networks, from the ones which interested directly to economic operation, such as accounts, market analysis, balance sheets and financial settlements, to the ones which referred to impressions regarding the everyday life of the society." (Furtado, 2006, p. 22). 
To fulfill those needs - affective, administrative, commercial, and of information - since the beginning of sixteenth century people started to organize systems of correspondence in Europe, which were based on the paradigm developed by the Taxis family in Castela and in the Holy Empire. The Taxis, or Tassis, came from the north of Italy, where originally this clan boasted Tasso surname and operated systems of mail exchange to big corporations and traders. Thanks firstly to the support of Maximilian I and latter Carlos V, they could create a postal network wich, in its best time, was spread out for all the Habsburg domain and whose last traces - in spite of selling parts of the monopoly to other particular ant the expropriation of services by the crowns in several regions in the following centuries - lasted until the decade in $1870 .^{7}$

Structures that shared the monopoly regime were created, thus, and they were in some particular explorers hands, with lines of transport regularly traveled (postal routes) and post houses, with the aim of exchanging messengers and horses. Such structures were available not only to attend the royal service but also the needs of people, upon due payment, which contributed to its costing. They shared room with others, informal, such as muleteer services, boatmen, and even some institutional systems, such as the walkers of Coimbra University. Sometimes this socializing happened in a competitive way, other times in a complementary way, so the official mail service used these other possibilities in regions where the maintenance of their own service was not interesting or viable.

In Portugal, 1520, king D. Manuel named Luís Homem, the knight of his house, as the "postmaster general" of the Kingdom, with monopoly of mail service whithin a limit of five leagues surrounding Lisbon and the mission to organize the mails toward the north of Portugal and Elvas (border with Spain). After Iberian Union, other occupations related to mail service were created, called "lieutenant", "assistants", or even "postmaster general from place X”. They were not always subordinated

7 About the beginning of modern mail services and Taxis, check the following authors, among others: FERREIRA, 1963, p. 10; BEHRINGER, 2006, p. 333-374; MARTÍNEZ BAEZA, 2014, p. 25-31; GAZAGNADOU, 2013, p. 103-104; CAPLAN, 2015, p. 25-32. 
to the headline in Lisbon. In 1606, the postmaster general of the Kingdom was sold, irrevocably, perpetually and hereditarily, to Mata family, when all the other existing mail services were subordinated to them. The centralization of Portuguese mail service, just like happened in Spain, in practical terms, was being done by a sum of factors, in a slow process which ended only in 1728 , with the extinction of postmaster generals in Braga. In the middle of eighteenth century, according to what is testified by sources like Portugal Sacro-profano, by Paul Dias Niza (1758), the Kingdom was provided with a capillary postal service network, despite the existence of persisting complaints regarding the slowness and deficiency of the services. ${ }^{8}$

However, in transcontinental monarchy case, it was not enough to build a communication network only in Europe. In 1657, the king D. João IV created the postmaster general of sea letters, in order to organize the loading and unloading of all correspondences carried by ships. According to the statute of the new service, the letters should be put into closed bags, under supervision of assistants designated by the postmaster general. These assistants were in charge of collecting the letters that arrived at the harbor, list them and make them available to the addressees, upon charging. Besides that, the holders of the craft assumed the obligation to provide despatch vessels whenever the crown demanded, to any location in the empire, with exception of India, not included in the new monopoly. ${ }^{9}$ The craft was sold to the same Mata who had acquired the mail service of the Kingdom. Only in November 1662, however, the first ultramarine assistants were designated (Bahia, Pernambuco, Rio de Janeiro, Cape Verde, Terceira Island, and Madeira). As to some of them, there is no sign that they have effectively held the

8 About the history of Portuguese mail service in Old Regime, check the following authors: FERREIRA, 1963; FIRMINO, 2005; SOBRAL NETO, 2005; MACHADO, 2008; SALVINO, 2015a.

9 Postmaster general of sea letters statute, apud DOCUMENTOS dos séculos XIII a XIX relativos a correios. Lisboa: Fundação Portuguesa das Comunicações, 2008. p.239. "Despatch vessels" were both the ones which, integrated into the fleet, carried the mails, and "untied ships", which were sent on an extraordinary basis with the same purpose. 
position. The first one to take position was João Cavaleiro Cardoso, in June 1663, in Rio de Janeiro. Generally speaking, these officers faced strong opposition from Municipal Councils and businessmen, who protested against what they called an "unfair tax". In Bahia, the Municipal Council alleged that the same service was provided, efficiently and free of charges, by the water bailiff. Still in Bahia and also in Pernambuco there were complaints that the need of making lists of letters which were received, according to the Statute of Mail Service, delayed the release of the load. That, according to some claims, would cause the death of slaves arriving from Angola, who could not be released from the ships until the addressees of the letters received them. Thus, some of these assistants did not get to hold position. Others worked for longer periods, thanks to judicial decisions in their favor, even getting to bequeath it to their homonym sons - that was the case of Bartolomeu Fragoso Cabral, in Bahia. ${ }^{10}$

The opposition from the Municipal Councils and the businessmen, on both sides of Atlantic, was made in the name of old habits and economic matters. In Portugal, there was not such adverse and continued reaction as happened in Brazil, which can be explained, among other reasons, by the fact that the mail service of the kingdom effectively carried the mails from one place to another, that is, there was the provision of a service more tangible than the sea mail service implemented in Brazil. This country was responsible only for the transport and collection of letters carried by the fleets and for the delivery to addressees in port areas, without delivering to any other location, an activity which seemed to be simply parasitic.

However, the postal service faced opposition not only due to economic reasons but also due to the defense of certain uses and habits. A factor which was not always made explicit, but that was important in decision-making, was the fear that the official mail service could serve as a device of censorship and spy. A fear that the secrets of communication

10 Regarding assistants of the postal service in Portuguese America, check the following author: ROSÁRIO, 1993; MACHADO, 2008; SALVINO, $2015 b$. 
were violated emerges on office documents and on the missives themselves. There are cases when the texts mention a possible scrutiny of correspondence by unwanted eyes, which led to deceiving strategies like the use of ciphers, invisible ink, or the sending of more sensitive letters only through reliable hands. A concrete example of the use of mail service as an instrument to control information was the so-called "black cabinets", used in many European countries, over seventeenth and eighteenth centuries, in order to spy letters, under allegation of "reasons of state" (Caplan, 2016, p. 95-123). Even Portugal, had its own "opening cabinet", during the reign of D. João V, dedicated to the choice, violation and copy of correspondences which were thought to be in the best interest of the crown business (Silva, 2009, p. 85). Such missives were selected by taking into account its sender and addressee, or even their geographical origin (countries which were considered enemies or whose exchange of information was interesting to be controlled for any reason). Alexandre de Gusmão, who had important role in packet boats history which is told in this paper, took part in such activity, by contributing not only to decode secret letters written by France and Rome, but also to develop Portuguese ciphers, supposedly inviolable (Silva, 2009, p. 203). Taking into account that the postmaster general was the responsible, at least officially, not only by the processing of the correspondences whithin Portuguese territory but also by postal exchanges with colonies and also the reception of letters which came from other countries, it was hard to imagine that he did not join gossips like these, which worsened opposition to his service. ${ }^{11}$

11 Examples of this kind of concern appears, for instance, in letters written by the Countess of Vimieiro, Teresa de Mello Breyner, to the future Marquise Alorna. See: BELLO VÁSQUEZ, p. $79-80$. 


\section{THE NEW SCENARIO IN EIGHTEENTH CENTURY AND THE FIRST ATTEMPT TO IMPLEMENT PACKET BOATS BETWEEN LISBON AND AMERICA}

The distance, which was already great between Lisbon and the main Atlantic colonial centers, became even wider after the discovery of gold mines at the turn of seventeenth to eighteenth century. The new reality, in which America became the most precious jewel of the crown and in which the fear of foreign invasions and internal insurrections grew, demanded an improvement in communication between the Kingdom and its colonies. Schematically, one can say that such improvement depended on three kinds of providence. The first one was related to the speed and regularity of crossing the Atlantic. The second one was related to the safety and control of operations of importation of letters in Brazilian harbors. The third one was related to the storage of those correspondences on American soil, in order to attend the settlement borders, where the crown constituted new administrative units.

Regarding the second and third aspects, between 1710 and 1712, new assistants were designated to work in Rio de Janeiro, São Paulo (for the first time) and Bahia. The representatives designated to work at these two latter places did not even hold office, because they faced opposition in Municipal Councils. The assistant in Rio de Janeiro, Antônio Alves da Costa, even connected that city to villages in Minas Gerais for three years, when the governor Francisco Xavier de Távora, forbade him from doing so, due to an unknown reason. That decision would be partially confirmed by $\mathrm{D}$. João $\mathrm{V}$ himself in 1730 , when he forbad that the postmaster general created postal lines in Brazilian interior (Salvino, 2014).

In search of speed and regularity when crossing the Atlantic, attempts to implement packet boats between Lisbon and Brazil were registered between 1710 and 1745 . It is important to remember that, by that time, the connections between these two sides of the ocean had its pace regulated by the fleet shifts, producing pauses, standby time, which 
made the delay in communication worse. ${ }^{12}$ The opening of periodical maritime routes in order to carry correspondences, by emulating similar systems implemented by the English people, would enable not only more speed in communication with the colonies but also a better planning of the business. By that time, except for cases of disobedience to the law, between one fleet and another, the hugeness of Atlantic was only disrupted by sporadic despatch vessels, which was an extraordinary solution because of its high cost. This situation occasioned irregularity and slowness in exchange of correspondences, besides generating great expenditure every time that a more urgent communication was needed. Such reality emerges clearly in an opinion by Alexandre de Gusmão dated 1745:

Each time that a warning with the news of the arrival of the ships from India is issued in Bahia, even if they come full of tobacco and they are commonly big ships, those ships cost your Excellency a great price. The same and much more expensive thing has happened when warnings were sent from Rio de Janeiro, and when they were sent here from Brazil. ${ }^{13}$

That way, the sending of regular mail ships could be a more rational solution, by enabling a planning of solutions and a sharing of costs between several agents. The same process in 1745 allows us to verify that some similar pleas had already been analyzed some decades before. The former one seems to belong to a certain Manuel Alves Nogueira, in 1710. In Gusmão's opinion there are mentions of a similar proposal, dated 1735 , which would have been analyzed by a committee of notable

12 The fleet system took its first steps from 1632, when a royal letter determined that ships going to Brazil should depart from October and February, and in 1649, when the Companhia de Comércio do Brasil (Company of Commerce in Brazil) was created. This system would be consolidated with provision from July 24th 1660, when isolated trips, the "untied ships" were forbad. Such obligation went on until 1766. About this subject, check the following authors, among others: PINTO, 1979, p. 133-184.

13 Request, 1745. 
men, summoned by the king D. João $\mathrm{V} .{ }^{14}$ The case must have been analyzed only at this petit comité, without going through the Conselho Ultramarino (Ultramarine Council). In his vote, Alexandre de Gusmão only mentions papers whose copies were in his hands, but they were not in official records. There is no indication of whom the proponent would be, but it is known that he would be a foreigner. That was the reason why, at the end, the sovereign had denied the projects, in spite of the favorable votes which were received. By that time, few businessmen would have been heard. Also in 1745, on counselor Manuel Caetano Lopes de Lavre's opinion, there is a reference to an event when the mail ships, after being authorized, ended up forbidden before the first trip, because smuggling was found inside them. However, references to the episode are vague, because they allowed us to identify neither when it happened nor the characters who were involved.

At the first attempt to introduce the packet boats, Manuel Álvares Nogueira sent a petition, from London, through a letter by Manuel de Siqueira Crespo. The case was analyzed by the Conselho Ultramarino, in accordance with a royal decree of January 31 st 1710, in which the monarch requested to hear businessmen regarding the subject. In this case, they were represented by the Confraria do Espírito Santo da Pedreira (Brotherhood of Holy Spirit of Pedreira), a fraternity founded in fifteenth century in order to inspect market practices and to represent the interests of tradesmen from Lisbon. The entity gained more importance in the following decades, through the Mesa dos Homens de Negócio que Conferem o Bem Comum do Comércio (Board of Businessmen who Confer Common Good to Commerce), but it already had great influence by the time the depicted episode happened. ${ }^{15}$

14 Among the examiners, there were the Marquis of Alegrete, Alexandre de Gusmão himself, and the appellate judges João Álvares da Costa and José Vaz de Carvalho, besides others judges and theologians. As a representative of businessmen, Manoel Gomes de Carvalho e Silva, Manoel de Sande de Vasconcelos, Francisco Luiz Saião, Antônio Vaz Coimbra e Francisco Gomes Lisboa were heard.

15 About the Mesa do Espírito Santo (Board of Holy Spirit), check the following authors, among others: FALCON, 1988, p. 10-14; ALBUQUERQUE, 2016, p. 24. 
In packet boats episode from 1710, the preponderant voice belonged to those businessmen, conveyed by the counselors. On the other hand, if the king was careful by demanding to hear them, the process does not make explicit any sign that the postmaster general was involved with it. This absence draws the attention because, from normative point of view, the reception of cargo by the packet boats was an assignment attributed to sea letters assistants, even if, from the practical point of view, this did not happen regularly in American harbors. Besides that, it is important to remember, the postmaster general was regimentally compelled to provide despatch vessels whenever they were needed - a duty which could be invoked as a right, if there was possibility of earning. This fact used to give rise to judicial challenge.

Manuel Álvares Nogueira's petition was rejected. They alleged that it was "full of great artifices", because it answered not only the proponent's interest but also "the vassals' of English Crown". ${ }^{16}$ That is, they did not question risks related to confidentiality of correspondences, problems related to high costs or delay in delivery, as usually happened when there were clashes regarding the designation of assistants of the postal service. They questioned, on the other hand, a broader aspect, that is, the possible provision of precious ultramarine domains to foreign interests. It was in evidence not only a closer interest by the commerce but also a matter of more general scope, articulated with the defense of greater objectives of the kingdom.

However, on the same Consultation:

one recognize that the existence of packet boats will be useful in service of your Majesty, because we will be able to know the condition of Colonies Governments in order to promptly help them from this Kingdom whenever necessary, and, in consequence, the usage of them will be good for the commerce, because the tradesmen can use the those warnings in order to easily and better make their fortune. ${ }^{17}$

16 Consultation, 1710.

17 Consultation, 1710. 
A curious rhetorical game flourishes here. After rejecting the original proposal in the name of Portuguese interests, it is stated that the solution would be of great use to the royal service. The speed in communication provided by the packet boats enabled to attend the colonies with more agility, whenever it was necessary. Subsidiarily — and "in consequence" - , the commerce could also use them, so the tradesmen could "easily and better" make their fortunes. The adduced argument here - in which the businessmen's interests are finally mentioned in a direct way — intends to push their objectives aside. According to the reasoning here exposed, the eventual creation of packet boats would meet the royal service's interests rather than private purposes. Such effort could hide a caution against those ones who intented to be the main funders of a system which would certainly have high costs, taking into account the long Atlantic crossings, in which the risks multiplied.

The original petition was rejected, but the counselors took the opportunity to state that "as the members of the Confraria do Espírito Santo offered us to provide the packet boats, Portuguese businessmen should accept that proposal". ${ }^{18}$ That is, at the same time that they were against a hypothetical foreign intervention, the brotherhood took the opportunity to present themselves as possible runners of the proposal, seeking to kill two birds with one stone, by eliminating a virtual competitor and by offering an opportunity of earnings for themselves, with financial support of the crown.

The opinion of Conselho Ultramarino, however, was that the members of the Confraria do Espírito Santo should be subjected to the same conditions presented by the requester and "navigate like the English ones do". ${ }^{19}$ Such demand may have become an obstacle to the continuation of the brothers' proposal. If that was real, or because it was a bluff, the packet boats sponsored by them never departed for the sea. This way, over three decades later the matter would keep being discussed, with the members of the Confraria do Espírito Santo now in open opposition not

18 Consultation, 1710.

19 Consultation, 1710. 
only against the proponent of the idea but also against the mail ships, by trying to raise a series of arguments against the implementation of this procedure. That is what we are going to check hereafter.

\section{FROM FORMER HARPSICHORD TEACHER TO POTENTIAL SHIPOWNER OF PACKET BOATS AND CONTRACTOR OF WHALE FISHING}

After this first attempt to launch packet boats between the Kingdom and America, as we saw, there were others, until the mid-1740s, when Francisco Peres de Sousa's plea appeared. He was assistant of the postal service, and requested the authorization to create bimonthly connections between Lisbon and the main places in American coast by that time - Rio de Janeiro, Bahia and Pernambuco.

The requester, in this case, was a character a little better known than the protagonist of the last episode, Manuel Álvares Nogueira, even though he deserves a monographic study. Francisco Peres de Sousa was a businessman from Lisbon, who, from the decade of 1740, stretched a large network with a close connection with Portuguese colonies in America. His relationship with Brazil came before the history told here, because Alexandre de Gusmão, in his opinion on the packet boats, break the news that Peres de Sousa had been, in the years of 1740, in Rio as a treasurer of dead and absent people. In 1753, he got the contract of wine and brandy subsidy in Rio de Janeiro for three years. Since 1754 he joined, with other partners, the contracts of whale fishing in Brazilian coast, which he took upon himself for the following period, from 1761 to 1765 . He was one of the main organizers of the Companhia da Pescaria das Baleias nas Costas do Brasil (Company of Whale Fishing in the Coast of Brazil), founded in 1765, and also named Inácio Pedro Quintela e Companhia (Inácio Pedro Quintela and Company), which unified the monopolies related to whaling activity and got contracts from that year. This second name of the company sounds like it was only Quintela's property. Myriam Ellis, in one of the most complete studies published on whale fishing in colonial Brazil, presents him as the head of the business (Ellis, 1969, p. 43; 154-157). 
There are records, however, that the greatest part of the company capital belonged to Peres de Sousa (Paz, 2015, p. 66). If this information is accurate, it is very likely that the concealment of the greatest partner's name happened because, in 1764, he had been accused of misapplication when he worked on a previous agreement and of having his goods sequestered in Bahia. Peres de Sousa, however, overcame the problem and continued getting other contracts during the following decades. In 1774, in D. Maria I's government, his name reappears along with other partners' names, when he got again, for twelve years, the exploitation of whale fishing in the whole Brazilian coast and adjacent islands. This contract also included the production of oil and its provision to Rio de Janeiro, Santos and São Vicente villages, Santa Catarina island, besides Cabo Frio. In 1782, year when he died, he got the contract to monopolize the exploitation of salt in the state of Brazil along with other entrepreneurs.

But his life was not only composed of contracts and money. In 1771, he was one of the founders of the Sociedade Estabelecida para a Subsistência dos Teatros Públicos da Corte (Society Established to the Maintenance of Public Theathers of the Court), along with many other important businessmen. That was a patronage initiative, but it was also an evident search for social luster. ${ }^{20}$ The world of arts was not strange to him. During the packet boats process in 1745, the counselor Manuel Caetano Lopes de Lavre accused him of being an upstart, without any resources to take over the proposed contract. He supported this charge on the recollection that the requester would be known, a little bit before, as a teacher of "music and harpsichord in several private houses of this court". ${ }^{21}$ That humble origin is a possible sign that Peres de Sousa had been, at least at the beginning of his career, someone's stooge.

20 About Peres de Sousa's trajectory, of whom I got only sparse information, check: AHUCU-005-01, cx. 38, doc. 7011-7017; AHU- Rio de Janeiro, cx. 53, doc. 64; AHU-Contracts of salt, cx. 1, doc. 75 e 76; COLLECÇÃO da legislação portugueza desde a ultima compilação das Ordenações, redegida pelo Desembargador Antonio Delgado da Silva. Legislação de 1763 a 1774. Lisboa: Typografia Maigrense, 1829, p.761-766. Also see: GONÇALVES, 2014; PAZ, 2015.

21 Requirement, 1745. 
The packet boats proposal happened, therefore, almost a decade before Peres de Sousa got his first contract of whale fishing. Certainly, in order to minimize the opposition which was already known to be hard, the proposal was presented in a unusual and oblique way - something that was ironically called, in the course of the process, "a fair appearance of charity" 22 - that is, through a requirement of the head nurse and treasurer of the Royal Hospital.

The cited nurse, without mentioning possible earnings of the requester, highlighted that, in case the request was accepted, annual donations would be offered to the "miserable nurses", so they would be aided "without neither Royal Finances nor the people had any loss". According to the request, Francisco Peres de Sousa, named by the postmaster general as his assistant in Brazil, commited himself to always having available "as many packet boats as needed, so they can come and go every two months to main harbors in Brazil, namely, Bahia, Rio and Pernambuco, so that there will be in this Court, every two months, news coming from them, which will be useful to the commerce of the Kingdom and its public government". 23

That is, according to the initial view, conveyed by the diligent nurse, the common good would be attended in many ways: aid to nurses, without any onus for the crown and the people, as well as advantages to commerce and royal administration, due to a fast communication with Brazil. The proposal also presented some news regarding the operation of postal service assistants overseas. Peres de Sousa enlarged the regimental duties attributed to those officials, by stopping being a mere intermediary of harbor operations, so he could take over the transport of mail between the Kingdom and American colonies. From what was presented in many passages of the process, it is possible to conclude that, in order to enable the business, six seven-ton boats would be used - small size, thus - to navigate across the Atlantic on the three mentioned routes, one of them coming and another going. Besides papers, whose regular

22 Requirement, 1745.

23 Requirement, 1745. 
and fast transport was the main goal of the project, these ships would also carry goods, so the main earnings of each operation should come from them. Salt and foodstuff, on the way from Lisbon to Brazil; on the return trip, products from the land, except tobacco, in order to protect the commerce of this good. In those operations, obviously, the officials of postal service - Francisco Peres de Sousa himself, in Brazil, and the postmaster general, in Lisbon - were supposed to provide with resources related to activities of expedition and delivery of the correspondences which were in the harbors.

The records own a great number of arguments in favor of the packet boats, but they also present a series of objections, from common to unusual, not only against the boats but also against the requester. During the process, the members of the Confraria do Espírito Santo were against the idea once again, as well as the attorneys of the crown, who echoed their arguments. Strictly speaking, the first ones should speak on behalf of the common good of the commerce, and the second ones should defend the royal interests, but both arguments were combined and reiterated. The postmaster general and the contractor of salt, since there was the intention of transporting this product by the packet boat, were consulted due to their particular interests. The opinion of the postmaster general, Luís Vitório de Sousa da Mata Coutinho, as it would not be different, was favorable to the project. It draws the attention the fact that Peres de Sousa presents himself as "postal service assistant for the state of Brazil". All the former officers at the postal service in Portuguese America were designated to a specific place: Bahia, Pernambuco, Rio de Janeiro, São Paulo and Santos. Peres de Sousa's title seems to be, thus, unique and, probably, it should explain directly the intended mission in packet boats case, that is, the intention to connect through postal routes the city of Lisbon and the three most important cities in Brazilian harbors. In other words, by naming an assistant with such differential, there would be a direct participation of the postmaster general, even being marginal, in the formulation of the proposal. This is stated in the following part of Mata Coutinho's opinion: "I have no doubt that the requirement should be accepted [...] it will always be up to me the right 
of being postmaster general of the sea, as the agreement by the petitioner Francisco Peres de Sousa proposes". ${ }^{24}$

The subject, after being studied by the postmaster general, by the contractor of the salt, and by the attorneys of the crown, was only analyzed by the Council in 1749. Their opinions were divided, but there was a result of four against one in Peres de Sousa's favor. As we saw, Manuel Caetano Lopes de Lavre was totally against the project, by restating the objections of the attorneys and the members of the Confraria do Espírito Santo. Alexandre de Gusmão, on the other hand, strongly defended the idea. He suggested improvements in the writing of the original proposal, presented a history of previous similar attempts and the reason why they were not successful, and he also tried to refuse one by one all the opposite arguments. Regarding the members of the Confraria do Espírito Santo, Gusmão was extremely hard and ironic in several parts of his vote, by accusing them of not being able to judge the petition and of opposing to it just because they would not profit directly. He also accused them of not thinking about the good of the commerce, the royal service and the people, as we can see in the following passage:

It is not the first time that [...] that Board, by the undeserved title of caring for the common good of the commerce, does nothing but reject everything that could be of public utility whenever its members do not have any direct interest in the proposed business. And the same Counselor expects that your Majesty forgive his care when representing you, because it is such a indecorous thing to your royal service and to the Kingdom that the most important points of navigation and commerce be decided by a brotherhood whose members do not have the necessary knowledge to vote..$^{25}$

24 Requirement, 1745 - my emphasis.

25 Requirement, 1745. 
By the end of this process, he was followed by Diogo Rangel de Almeida Castelo Branco and Fernando José Marques Bacalhau, both of them named as members of the Council few days before, on November 3 th in that year. ${ }^{26}$ The first one was in favor of a three-year concession, so the results could be evaluated. It seemed, thus, at least from the part of the Council, that everything indicated a happy solution to Francisco Peres de Sousa's proposal.

The objections to the packet boats, expressed in the opinion of the members of the Confraria do Espírito Santo and of the royal attorneys - who, in practice, echoed those ones -, could be summarized in some axes. They represent both the economic difficulties to put such a project into practice, and the commercial and administrative thinking of that time, which were related to hesitations by new realities. In a sense, it can even represent the way people perceived time and distance.

The first group of reasoning could be summarized in the following argument: in order to sustain economically the project, it would be necessary, on the trip coming from the Kingdom, the transport of various kinds of goods, which would spoil both the commerce, it is important to say, and the competition and monopolies constituted until then. A supposed sending of dry goods off the fleets season would harm other tradesmen. The profitability of the return trip, on the other hand, would be spoiled by the fact that Brazilian goods had a low unit value. In order that the route could be economically viable, the ships should enable the transport of cargo, while the packet boats were, due to the demands of the postal operation, smaller boats. Thus, as the opinions said, "it is evident that in the return trip there will be no room in those small ships for sugar, tobacco and leather, which are common in Brazil". ${ }^{27}$ Expecting that the whole profit came on the outward journey, on the other hand,

26 Check the list of Counselors with the dates of their possession in: LISTA de Conselheiros - Conselho Ultramarino (1643-1833). Available at: <http://actd.iict.pt/eserv/actd:CUF007/ Lista_CU_Conselheiros.pdf >. Accessed on: 08/07/2017. Specifically about the naming of Bacalhau, check: AHU_ACL_CU-089, Cx. 4, D 395.

27 Requirement, 1745. 
would mean that this route would do "damages to the commerce and to the Royal Finances, which is enough to deny this request". ${ }^{28}$

The second important objection was that the packet boats, because they did not travel along with the fleets, would be hard to inspect, and so there would offer an opportunity for tax evasion and for diversion of the most profitable goods in South America: the precious metals. It is possible to read in some passages, on the opinion by one attorney of the crown, for instance, that "in many ships which so frequently would reach Brazilian harbors, it would not be possible to avoid diversion, not only of taxes owed to the Royal Finances [...] but also the diamonds, the gold, which will be diverted in great abundance". 29 This echoes the opinion by another attorney: "and a great door to the extraction of gold and diamond will be open". ${ }^{30}$ This flaw in the project would be boosted by the alleged lack of profitable products available to that kind of ship on the return trip, statement that is explicit on counselor Manuel Caetano Lopes de Lavre's opinion: "Being the cargo of the packet boats from this kingdom to Brazil more important than the cargo which they can bring to this court, some people will take greatest importance in diamond and gold powder". ${ }^{31}$

To reinforce this argument, they remembered supposed cases of smuggling which were run by English packet boats. This problem has already been remembered by Kenneth Maxwell, who included warships and mail ships from Falmouth among the villains responsible for the diversion of gold and diamond from Lisbon (Maxwell, 1999, p. 94). Alexandre de Gusmão, however, refuted it, with a certain irony: “They compare the diversion of rights and the smuggling which can be done through these packet boats with what is done in this harbor by English boats. They do so as if in the packet boats it happened that way just

\footnotetext{
28 Requirement, 1745.

29 Requirement, 1745.

30 Requirement, 1745.

31 Requirement, 1745.
} 
because they were called packet boats, and not because they were a kind of ships of war exempt from inspection". 32

The third argument against the proposal was related to the fear that foreigners could take over the wealth and information in Brazil. The counselor Manuel Caetano Lopes de Lavre said directly: "As this project is a wish of foreigners, we should proceed with great caution, because they have tried repeatedly to introduce their commerce in the state of Brazil". ${ }^{3}$ This risk, according to Lavre, would be greater due to the fact that Peres de Sousa, a former music teacher, had neither experience nor resources for the endeavor. The representatives of the Confraria do Espírito Santo, on their turn, claimed that, by having fast and privileged information - because they could know "in advance the products that exist in Brazil" - , the smart foreigners would act fast in order "to regulate prices, according to the quantity". Once again, the most vehement defense was made by Alexandre Gusmão. Regarding the first matter, he stated that, still being true that the packet boat business had external promotion, which was a suspicion without proof, "who, among those brothers and among all tradesmen in Lisbon, does business in Brazil with own resources and without depending on foreigners?". ${ }^{44}$ Regarding the second matter, it would be only a "imaginary damage", because if "the products that the foreigners will buy, or despise, will come by the fleet, what does it matter if they knew in advance whether the land had produced much or little? It seems that it makes no difference by the time the same products arrive" 35 - such reasoning, that is true, could be applied to those kind of products of more immediate sale and consumption but it could not be applied to products which can be stocked for a long time.

In a diffuse or direct way, permeating all those judgments, it is possible to identify the inquiry into the need of such assiduous trips to

32 Requirement, 1745.

33 Requirement, 1745.

34 Requirement, 1745.

35 Requirement, 1745. 
Brazilian coast. One can notice it, for instance, when one of the attorneys of the crown talks about "several ships which so frequently must reach almost every harbors in Brazil", in a passage which was already quoted here. Or when, in a more explicit way, Lavre disapproves the "whish for news that these Brazilian packet boats can provide, something that the businessmen do not want". ${ }^{6}$ That is an argument that Alexandre de Gusmão also rejected, by accusing the members of the Confraria do Espírito Santo of not being sympathetic to transcontinental business and of not noticing the advantages of a fast and regular communication for making the orders, managing inventories, and controlling the trade representatives, among other possibilities. These are differences of perception which can be explained by a bigger or smaller experience in dealing with ultramarine matters, but they are also related to distinct points of views regarding geopolitical and geoeconomic articulation in territories so far away - a clash over that constitutive discontinuity in societies of Ancién Regime - and they were also related to the way of understanding that relation between time and space highlighted by Braudel. In this aspect, despite of any other reasons to be against the packet boat they could have, men like the representatives of the Confraria do Espírito Santo and other officers of the crown could not see the advantages of a faster communication with the colonies, whether for business or for administration. That happened precisely because the overseas lands were seen as faraway parts of a naturally discontinuous reality and, for this reason, seemed to be immersed in another time regime.

\section{FINAL REMARKS}

It is a fact that, after four years of postponement, Francisco Peres de Sousa apparently had got a large majority of four votes to one among the members of the Council. However, something which happened on the backstage reversed the result. Therefore, in November 26th 1749,

36 Requirement, 1745. 
the counselors signed an opinion in order to put an end to the claim of the postal service assistant, which we can see in the following passage:

The Council seems to be comfortable with the answer of the businessmen concerning the damages to commerce, and with the repugnance of the attorneys regarding the damages to Royal Finances of your Majesty; it does not dare to approve a will which was denied so many times by the intelligent and scholarly ministers, by considering the pernicious consequences which can follow and by considering that it is safer to rule this process as it has been ruled up to now. ${ }^{37}$

In spite of this setback and the existing knowledge gaps regarding this episode, it is important to highlight some aspects. First, the emphasis given to a matter which was able to mobilize important businessmen and some organs of central Portuguese administration, in more than one occasion, over the decades. Second, the evidence that, in the movement of the involved agents, an element has been repeatedly invoked, in practically every political clash on written communication, that is, its importance to the governance and the commerce. Another specific element to be highlighted is the fear of foreign presence, this tension between the need of communicating and the inclination to cut the possible entrance ways for alien greed.

Contemplated at the present time, the arguments which were presented by that time against the packet boats may sound fragile, and Alexandre de Gusmão's opinion exposes this fragility with cleverness. The packet boats were too small to harm the commerce. The fact that they were stuck in a predetermined route, with a travel time somewhat certain (subjected, of course, to the mood of the sea and the wind), would prevent, or at least make it harder, the temptation for adventures in unplanned harbors. The supposed economic unviability of the project was a risk of the requester, because if he accepted the writing of the contract proposed by Gusmão, he would be subjected to heavy duties in case he did not comply with

37 Requirement, 1745. 
some of the clauses. Eventual smuggling could be inspected at the entry harbors, as it was pondered by Gusmão - this should be done, by the way, with any ship which did not have diplomatic protection.

However, since the first moment, in 1710, it was evident that the grudge of the member of the Confraria do Espírito Santo against the "arbitrators" who presented the idea and, evidently, their opposition were decisive for the refusal of the projects over the years. Trying to attribute those setbacks only to conservatism, selfishness and lack of intuition of the members of the Confraria, as Alexandre de Gusmão did, would be reductionist though. In the episode of 1735, it seems that the Board was deliberately removed from the scenario; however, the origin of the requester, who was a stranger, was decisive in that opportunity. And there was a case when people found out that some ships, which were allowed to leave the harbor, presented evidences of smuggling - and this case was probably reported by the people who were against the idea. This may have contributed to subsequent hesitations of the sovereign. It seems clear, in those many events, the weight of king D. João V's personal decision. This decision was against the opinion of his main counselors even though. However, some cultural elements regarding the conduct of the subject cannot be ignored, in the several times it came out. In this field we can situate the necessary effort to communicate with the various regions which composed the monarchical body, and the inclination to hide the colonies, full of real or imaginary wealth, from foreigners. The fleet system, alongside pragmatic reasons like defending the ships against virtual attack of enemies, should contribute to escape from malicious ships. Besides that, the understanding of that relation between time and space which was mentioned in the first part of this paper cannot be forgotten. With respect to this understanding, on the one hand, some time intervals, which are inadmissible nowadays, did not seem excessive at that time; on the other hand, those "insular groups", which constituted the world and the monarchy, seemed to be natural, and they should be connected only for a particular purpose, by concrete demands.

Thus, the launching of the packet boats was nothing but an intention, despite all the praise in its favor. The transport of letters over the Atlantic 
should go on depending, during the following years, on the slow pace of the fleets and, in exceptional cases, on despatch vessels launched at great expenses. The Confraria do Espírito Santo was extinguished by Marquis of Pombal, in 1755, because they were against the new companies of commerce. In such occasion, some of its main members were arrested and banished (Falcon, 1988, p. 13). In 1760, a royal decree allowed that the contractors of whale fishing could carry the oil taken from these animals, off the fleet system, in six-hundred-ton ships - therefore, with a carrying capacity ten times larger than the packet boats. ${ }^{38}$ Francisco Peres was one of the main favored by the measure. This was the first hole in the system of fleet, established in the previous century, and which would be definitely closed six years later. It is not excessive to think that those boats which carried whale oil had also been used to carry correspondences, by complying, at least in part, the role of the despatch vessels or the packet boats. From 1766, with the end of the fleets, any ship, at any time, could carry letters, no matter if they were smuggled or dispatched according to the rules of the Regiment of the Sea Letters Courier.

Across the ocean, who would receive them, however? The last known designations of officials to work at mail service in Portuguese America, except for Peres de Sousa, are to work in Santos (1735) and Recife (1738), less than a decade before the designation of our character to work as an assistant of the post service in the state of Brazil. A hypothesis is that, since then, the postal officers have been excluded from Portuguese America, either due to the opposition of the Municipal Council and the tradesmen, or due to the little economic attractiveness of this craft, or due to the combination of both causes. Thus, it was up to other local instances - as it happened to the water bailiff during the previous century in Bahia - eventually receive and open the bags of letters which were sent from the Kingdom, so they could deliver them. Another hypothesis - even more fragile, which depends on further research, but that should not be discarded - is that this task could have been performed, at some harbors like Bahia, Rio de Janeiro, Santos and Santa Catarina,

38 Torre do Tombo National Archive - Junta do Comércio, mç. 67, cx. 215. 
by Peres de Sousa's representatives, because he worked in those places as a tradesman, a contractor of whale fishing, of salt and wine, in different times. Subsequent documents in which the former harpsichord teacher has been identified as an assistant of the postal service were not found, but, at first, this position was lifelong. The exercise of this position, or at least the keeping of this right overseas by the whaler, could, thus, explain why, after several individuals have performed this office during the second half of seventeenth century and in the first decades of eighteenth, there is a sudden silence related to the documents since 1740 , exactly in a moment when, due to several reasons, the necessity of written communication between Portugal and its main colony has become more intense. The mere fact that, except for a mistake, Peres de Sousa has not appeared among the assistants of the postal service up to now, in the few historiographical studies on the postal system of the Old Regime, is a sign that not much is known about that matter.

The packet boats which were sent by the English people to their American colonies during the War of the Spanish Succession did not last much, because they were harassed by economic matters and by the mischances of the sea and war (Steele, 1986, p. 168-188). If Portugal had successfully implemented these projects on regular maritime postal routes in the first half of the eighteenth century, it could have anticipated long-lasting experiments with the same goals as those organized by the English people from 1755 and by the Spanish people from 1764. An important point of Peres de Sousa's project was the concern about the business financing, which also included the carrying of various fabrics. A chain of packet boats as the one which was proposed by the pioneers would only start to work from 1798, when the mail service was taken by the Portuguese crown. That happened during a process which was guided by a new geopolitical understanding of imperial network rather than more immediate economic reasons. Although these packet boats were directly managed by the Portuguese government, they used to carry some goods, such as wood, in order to subsidize part of their operation, which is another sign of the challenges they needed to face so they could economically keep that structure. Studying this history, which still 
has many gaps, by going through its meanders in that century, is way not only to understand a neglected aspect of written communication systems, a technology used to dominate the distance, but also to look closely at some changes in operation of those "empires of paper" whose management and business were spread over more than one continent. ${ }^{39}$

\section{ACKNOWLEDgments}

I would like to thank professor Francisco Cosentino, in memoriam, who encouraged me to proceed with the researches related to written communication in Portuguese America. I would also like to thank Empresa Brasileira de Correios e Telégrafos (Brazilian Post), which awarded me a scholarship to do so.

\section{Translated from Portuguese into English by: \\ Thiago Andrade de Paula \\ tiagoandp@gmail.com}

\section{BIBLIOGRAPHICAL REFERENCES}

ALBUQUERQUE, Tomás André Pinto de. Qual o papel das redes na construção da carreira de um grande homem de negócios e sua relevância para o funcionamento do Império? Dissertação (Mestrado em História Moderna) - Universidade Nova de Lisboa. Lisboa, 2016.

39 A crucial difference between the projects which we analyzed and those which were implemented in the second half of the seventeenth century is that the latter ones were managed directly by the crowns, which also gave financial support. About the English case, see STEELE, 1986, p. 273. Regarding the Spanish sea mail, there are several studies, including books by BELOTTO, 1971 and GARAY UNIBASO, 1984, besides articles by CABANILLAS, 2014 and ARANEDA RIQUELME, 2015. With regards to Portuguese maritime mail, created during postal reforms between 1797-1798, it is possible to check: SOBRAL NETO, 2005, p. 56-58; MACHADO, 2015, p. 227-249. 
ALGRANTI, Leila Mezan, MEGIANI, Ana Paula (orgs). O Império por Escrito: Formas de transmissão da cultura letrada do mundo ibérico, sécs. XVI-XIX. São Paulo, Alameda, 2009.

ANASTÁCIO, Vanda; MONTEIRO, Nuno Gonçalo: ALMEIDA, Teresa Sousa de (orient.). Correspondências (usos da carta no século XVIII). Lisboa: Colibri, Fundação das Casas de Fronteira e Alorna, 2005.

ARANEDA RIQUELME, José Araneda. «Una correspondencia mensual, semanaria y a todas horas»: correo y espacio en el imperio español durante las reformas borbónicas, siglo XVIII. In: SEMINÁRIO Simón Collier 2014. Santiago de Chile: Pontificia Universidad Católica de Chile, 2015.

BELLO VÁSQUEZ, Raquel. Privacidade e publicidade: a correspondência pessoal como forma de intervençom nos campos intelectual e do poder. In: ANASTÁCIO, Vanda; MONTEIRO, Nuno Gonçalo; ALMEIDA, Teresa Sousa de (orient.). Correspondências (usos da carta no século XVIII). Lisboa: Colibri; Fundação das Casas de Fronteira e Alorna, 2005. BELOTTO, Manoel Lelo. Correio marítimo hispano-americano: a carreira de Buenos Aires (1767-1779). Assis (SP): Faculdade de Filosofia, Ciências e Letras de Assis, 1971.

BEHRINGER, Wolfgang. Communications Revolutions: a historiographical concept. German History, v. 24, n. 3, [Sheffield], The German History Society, 2006, p. 349-357. Available in : <http://www.mediastudies.asia/ wp-content/uploads/2016/10/Wolfgang_Behringer_Communications_ Revolutions.pdf>. Accessed in: 18 Sept. 2017.

BOUZA, Fernando. Corre Manuscrito: una historia cultural del Siglo de Oro. Madrid: Marcial Pons, 2001.

BRAUDEL, Fernand. El Mediterráneo y el mundo mediterrâneo en la época de Felipe II. 2 ed. 7 reimp. Madrid: Fondo de Cultura Económica, 1976. BRENDECKE, Arndt. Imperio e información: funciones del saber en el domínio colonial español. Madrid: Iberoamericana, 2012.

CABANILLAS, Rocío Moreno. El primer paquete a las Indias (1764): el Cortés, precursor de un nuevo sistema postal ultramarino. Revista de Historia Naval. 2014. Available in : <https://www.academia.edu/10259584/ El_primer_paquebote_de_correos_mar\%C3\%ADtimos_a_las_ 
Indias_1764_precursor_de_un_nuevo_sistema_postal_ultramarino._ En_la_Revista_de_Historia_Naval>. Accessed in 20 June 2017.

CAPLAN, Jay. Postal culture in Europe - 1500-1800. Oxford: Oxford University; Voltaire Foundation, 2015.

CASTILLO GÓMEZ, Antonio. Entre la pluma e la pared: una historia social de la escritura en los Siglos de Oro. Madrid: Akal, 2006.

ELLIS, Myriam. A baleia no Brasil Colonial. São Paulo: 1969.

FALCON, Francisco José Calazans. A prática mercantilista em Portugal durante a época pombalina: papel-chave da Junta do Comércio. Revista do Mestrado de História da Universidade Severino Sombra, p. 5 - 27, jun. 1998.

FERREIRA, Godofredo. Dos Correios-mores do Reino aos Administradores Gerais dos Correios e Telégrafos. 3 ed.. Lisboa: CTT, 1963.

FIRMINO, Glória. Subsídios para a história dos Assistentes do Correio-Mor de Portugal (Séculos XVI/XIX). Lisboa: Grupo dos Amigos do Museu das Comunicações, 2005.

FRAGOSO, João; MONTEIRO, Nuno Gonçalo. Um reino e suas repúblicas no Atlântico: comunicações políticas entre Portugal, Brasil e Angola nos séculos XVII e XVIII. Rio de Janeiro: Civilização Brasileira, 2017.

FRAGOSO, João; Maria de Fátima Gouvêa. Introdução: desenhando perspectivas e ampliando abordagens - De O Antigo Regime nos Trópicos a $\mathrm{Na}$ trama das redes. In: FRAGOSO, João; Maria de Fátima Gouvêa. Na trama das redes: política e negócios no império português, séculos XVI a XVIII. Rio de Janeiro: Civilização Brasileira, 2010. p. 11-40.

FURTADO, Júnia Ferreira. Homens de negócio: a interiorização da metrópole e do comércio nas Minas setecentistas. 2. ed. São Paulo: HUCITEC, 2006.

GARAY UNIBASO, Francisco. Correos marítimos españoles. Bilbao: Mensajero, 1987.

GAZAGNADOU, Didier. La poste à relais em Eurasie: la diffusion d'une technique d'information et de pouvoir - Chine - Iran - Syrie - Italie. Paris: Éditions Kimé, 2013.

GONÇALVES, Duarte. A Sociedade estabelecida para a subsistência dos Teatros Públicos da Corte - uma "companhia pombalina”. População e sociedade, v. 22, p. 195-206, Porto, 2014. 
HESPANHA, António Manuel. As vésperas do Leviathan: instituições e poder polítco. Portugal - séc. XVII. Coimbra: Almedina, 1994.

MACHADO, Luiz Guilherme G. História geral dos Correios portugueses nos séculos XVI ao XVIII. [s.l.]: [2008]. Available in: <http://historiapostal. blogspot.com.br>. Accessed in 24 Feb. 2017.

MACHADO, Luiz Guilherme. A criação dos correios marítimos entre Portugal e o Brasil em 1798. Postais: Revista do Museu Correios, Brasília, Empresa Brasileira de Correios e Telégrafos, ano 3, n. 4, p. 227-249, 2015. MARTÍNEZ BAEZA, Sergio. El Correo Mayor de las Indias y el ducado de San Carlos. 2 ed. Santiago del Chile: Academia Chilena de la Historia, 2014.

MAXWELL, Kenneth. Pombal e a nacionalização da economia lusobrasileira. In: MAXWELL, Kenneth. Chocolate, piratas e outros malandros: ensaios tropicais. São Paulo: Paz e Terra, 1999. p. 89-123.

PAZ, Marcelo de Oliveira. Companhia da Pescaria das Baleias nas Costas do Brasil (1765-1801): a caça ao Leviatã dos mares. Dissertação (Mestrado em Estudos Brasileiros) - Instituto de Ciências Sociais/Faculdade de Letras da Universidade de Lisboa. Lisboa, 2015.

PEDREIRA, Jorge Miguel. Os negociantes de Lisboa na segunda metade do século XVIII: padrões de recrutamento e percursos sociais. Análise Social, vol. XXVII, p. 412-413, 1992. Available in: <http://analisesocial. ics.ul.pt/documentos/1223054099R0pVP5xq0Uf71OV2.pdf>. Accessed in 10 Apr. 2017.

PINTO, Virgílio Noya. O ouro brasileiro e comércio anglo-português: uma contribuição aos estudos da economia atlântica no século XVIII. 2 ed. São Paulo: Companhia Editora Nacional, 1979.

RODRIGUES, Miguel Jasmins. Descontinuidade e comunicação: o reino e a construção do império. In: SANTOS, Maria Emília Madeira; LOBATO, Manuel (coord.). O domínio da distância: comunicação e cartografia. Lisboa: Instituto de Investigação Científica Tropical, 2006. p. 13-19.

ROSÁRIO, Irari de Oliveira. Três séculos e meio da história postal brasileira: 1500-1843. Rio de Janeiro: Empresa Brasileira de Correios e Telégrafos, 1993. 
SALVINO, Romulo Valle. Correios extraviados entre Lisboa e as Minas: uma contribuição para a história dos assistentes do correio-mor no império português (séculos XVI-XVIII). In: ANAIS do V Encontro de Internacional de História Colonial: Cultura, Escravidão e Poder na Expansão Ultramarina (Século XVI ao XIX), Maceió, Ufal, 2014. Available in: <https://docs.google.com/file/d/0B8qBHzOPM4O8VzFaelEzclZPekU/edit?pli=1>. Accessed in 10 Dec. 2016.

SALVINO, Romulo Valle. Patrimonialização e venalidade no provimento de ofícios no império português: uma abordagem preliminar do caso do correio-mor e seus cargos auxiliares (séculos XVI-XVIII). Postais: Revista do Museu Correios, Brasília, Empresa Brasileira de Correios e Telégrafos, ano 3, n. 5, p. 36-75, 2015a.

SALVINO, Romulo Valle. Uma breve história dos assistentes do correio. Postais: Revista do Museu Correios, n.4, p. 189-203, 2015b.

SELLERS-GARCÍA, Sylvia. Distance and documents at the Spanish Empire's periphery. Stanford: Stanford University, 2014.

SILVA, Maria Beatriz Nizza da. D. João V. Lisboa: Círculo de Leitores; Centro de Estudos dos Povos e Culturas de Expressão Portuguesa, 2009. SOBRAL NETO, Margarida (org.). As comunicações na Idade Moderna. Lisboa: Fundação Portuguesa das Comunicações, 2005.

STEELE, Ian K. The English Atlantic, 1675-1740: an exploration of communication and community. New York; Oxford: Oxford University, 1986. VIEIRA, Antonio. Cartas do Padre Antonio Vieira. Lisboa: J.M.C. Seabra \& T.Q. Antunes, 1854.

VIVO, Filippo de. Information and communication in Venice: rethinking early modern politics. Oxford: Oxford University, 2007.

VIVO, Filippo de. Patrizi, informatori, barbieri:politica e comunicazione a Venezia nella prima età moderna. Milano: Feltrinelli Editore, 2012. 